\title{
Infection and Death Patterns of COVID-19 Disease in Bangladesh
}

\section{Padrões de infecção e morte da doença COVID-19 em Bangladesh}

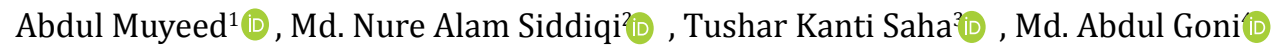

1. Department of Statistics, Jatiya Kabi Kazi Nazrul Islam University, Trishal, Mymensingh-2224, Bangladesh. 2. Department of Population Science, Jatiya Kabi Kazi Nazrul Islam University, Trishal, Mymensingh-2224, Bangladesh. 3. Department of Computer Science and Engineering, Jatiya Kabi Kazi Nazrul Islam University, Trishal, Mymensingh-2224, Bangladesh. 4. Department of Population Science and Human Resource Development, University of Rajshahi, Rajshahi, Bangladesh.

\begin{abstract}
Objectives: This study aimed to reveal the prevalence of COVID-19 and investigate the patterns of deaths due to novel coronavirus in Bangladesh. Methods: The data about daily incidences, sex and deaths by the geography of COVID-19 for Bangladesh as of August 29, 2020 have been collected from the daily press releases of the Institute of Epidemiology, Disease Control and Research (IEDCR) and Directorate General of Health Services (DGHS). Case fatality rates (CFR), doubling time, correlation coefficient and graphical presentation were used to investigate the prevalence and patterns of infection and deaths. Results: Infection to tests, recovery to infections and death to infection rates due to novel coronavirus in Bangladesh until August 29,2020 was $20.25 \%$, $64.37 \%$ and $1.36 \%$ respectively. The correlation coefficient between daily tests and infections has found 0.978 with a $95 \%$ confidence interval 0.971 to 0.984 . About 78.46\% male and only $21.54 \%$ of females have died. Most deaths were found in the Dhaka division (48.26\%) and the least deaths in the Mymensingh division (2.12\%). The sex ratio of males to females in deaths was $364.23 \%$. The age below 10 has found the least prevalent (0.45\%) to deaths and above 60 has found most vulnerable (49.26\%) to death. Conclusions: This study showed a strong positive relationship between daily tests and infections. The doubling time of infections and deaths in Bangladesh increased over time maintaining very low differences. Male people are more vulnerable to death compare to females. Aged people are extremely vulnerable to death. The most deaths geographical division is Dhaka and the least deaths in Mymensingh.
\end{abstract}

Keywords: COVID-19. Bangladesh. Severe acute respiratory syndrome coronavirus 2.Fatality. Infection.

\begin{abstract}
Resumo
Objetivos: o objetivo deste estudo foi revelar a prevalência de COVID-19 e investigar os padrões de mortes por novos coronavírus em Bangladesh. Métodos: os dados sobre incidências diárias, sexo e mortes por geografia de COVID-19 para Bangladesh em 29 de agosto de 2020 foram coletados dos comunicados de imprensa diários do Instituto de Epidemiologia, Controle e Pesquisa de Doenças (IEDCR) e da Diretoria Geral de Serviços de Saúde (DGHS). As taxas de letalidade (CFR), o tempo de duplicação, o coeficiente de correlação e a apresentação gráfica foram usados para investigar a prevalência e os padrões de infecção e mortes. Resultados: as taxas de infecção para testes, recuperação de infecções e morte por infecção devido a novo coronavírus em Bangladesh até 29 de agosto de 2020 foram de 20,25\%, 64,37\% e 1,36\%, respectivamente. 0 coeficiente de correlação entre os testes diários e infecções encontrou 0,978 com intervalo de confiança de $95 \%$ 0,971 a 0,984. Cerca de 78,46\% homens e apenas $21,54 \%$ mulheres morreram. A maioria das mortes foi encontrada na divisão de Dhaka (48,26\%) e menos mortes na divisão Mymensingh (2,12\%). A proporção do sexo entre homens e mulheres nas mortes foi de 364,23\%. A faixa etária abaixo de 10 apresentou menor prevalência (0,45\%) aos óbitos e acima de 60 foi considerada mais vulnerável (49,26\%) ao óbito. Conclusões: este estudo mostrou uma forte relação positiva entre testes diários e infecções. 0 tempo de duplicação de infecções e mortes em Bangladesh aumentou com o tempo, mantendo diferenças muito baixas. Os homens são mais vulneráveis à morte do que as mulheres. Pessoas idosas são extremamente vulneráveis à morte. A divisão geográfica com mais mortes é Dhaka e menos mortes é Mymensingh.
\end{abstract}

Palavras-chave: COVID-19. Bangladesh. Síndrome Respiratória Aguda Grave Coronavírus 2. Fatalidade. Infecção.

\section{INTRODUCTION}

The ongoing coronavirus disease 2019 (COVID-19) caused by novel coronavirus or severe acute respiratory syndrome coronavirus 2 (SARS-CoV-2) has been posing a serious threat to public health and the economy worldwide ${ }^{1-2}$. The disease is highly infectious and transmissible $e^{3-4}$ and on average each infected person can infect at least three persons ${ }^{5}$. The outbreak of COVID-19 was first reported in Wuhan, Hubei province, China in December $2019^{6-8}$. Since the identification, the number of people confirmed to be infected in China has increased day by day and rapidly spread out almost all over the world. The first confirmed death from COVID-19 was reported in China on January $10,2020^{9}$. The number of confirmed cases and the number of deaths due to COVID-19 increased at an alarming rate then it has attracted global attention and declared as the Public Health Emergency of International Concern (PHEIC) by the World Health Organization (WHO) on January 30, 20203,8,10${ }^{12}$. Due to its high infection rate, COVID-19 has caused extensive mortality and morbidity in most of the countries across the world $^{13}$. As the outbreak of COVID-19 spread rapidly to many countries, the WHO announced COVID-19 as a pandemic on 
March 11, 20205, 11,14,15. Globally, more than 24 million people diagnosed infected cases of COVID-19 have been reported by the WHO as of August 29, 2020, including 833556 deaths ${ }^{16,17}$.

The novel coronavirus (SARS-CoV-2) belongs to the same family of enveloped, positive single-stranded RNA groups of viruses that are responsible for different types of respiratory and gastrointestinal illnesses in humans, and many animal species $^{18,19}$. One COVID-19 infected person can infect other persons when they are in close contact through droplets of saliva discharge from the nose or mouth. These droplets are released from the mouth or nose when the infected person coughs, talks, or sneezes ${ }^{11,20}$. Infection with this virus can be asymptomatic or can result in mild to severe symptomatic diseases ${ }^{21,22}$. The most common symptoms of COVID-19 affected peoples are cough, fever, occasionally watery diarrhea, etc. with some other non-specific symptoms such as headache, dyspnea, fatigue, and muscle soreness that may develop within 2-14 days of infection $7,8,12,23$. According to WHO, other less common symptoms include loss of smell and taste, sore throat, conjunctivitis, a rash on the skin, or discoloration of fingers or toes ${ }^{24}$. Moreover, severe symptoms are difficulty breathing or shortness of breath, chest pain or pressure, and loss of speech or movement ${ }^{24}$. As compared to the COVID-19 patients without comorbidities, higher frequencies of severe cases and mortality are found among the patients with underlying comorbidities such as cardiovascular disease, high blood pressure, diabetes, and obesity ${ }^{25}$.

The COVID-19 pandemic is an emerging disease that has introduced exceptional challenges to healthcare systems worldwide which affects every country irrespective of the country's nationality, race, and economic status ${ }^{2,26}$. It is a global health emergency causing instability in every area of human life that has changed the world in an unprecedented way $y^{27,28}$. The impact and progression of the COVID-19 pandemic are strongly associated with the demographic composition of the population, specifically, age structure of the population ${ }^{29}$. The aged people are more susceptible to severe illness and more vulnerable to the COVID-19; the mortality is also high among the elderly population ${ }^{30,31}$. As compared to women, men who are suffering from COVID-19 have a greater risk of severe illness and worse outcome of the disease and higher mortality ${ }^{28,32,33}$. The morbidity and mortality due to COVID-19 from different areas and countries also express considerable geographic variations $s^{34}$.

Bangladesh is one of the densely populated countries in the world which is recognized as one of the most vulnerable countries in the world to be affected by the fast-spreading novel coronavirus ${ }^{35}$. Bangladesh has declared the first infected cases of COVID-19 on March 8, 2020, by its Institute of Epidemiology, Disease Control and Research (IEDCR) through a press conference ${ }^{28,36,37}$. The first confirmed death of coronavirus affected patients in Bangladesh was reported on March 18, $2020^{20}$. As of August 29, 2020, the confirmed cases of COVID-19 were 308925 in Bangladesh, and a total of 4206 deaths nationwide, with a case fatality rate of $1.36 \%^{38}$. Bangladesh is under the threat of out-breaking the novel coronavirus due to its insufficient preparedness to manage the COVID-19 pandemic ${ }^{39}$. Various vulnerabilities of this country intensify the impacts of COVID-19 and cause a multidimensional crisis $^{37}$. The government of Bangladesh along with different private organizations has taken several measures to fight against the COVID-19 pandemic ${ }^{36}$. To stop the outbreak of COVID-19, the Government of Bangladesh initiatives include compulsory home quarantine, restricting the movement of the people except for crying necessity and emergency health care, local or international flight bans, social distancing, the lockdown of some severely affected areas, and so on ${ }^{15}$. At present, Bangladesh is going through local and widespread national community transmission ${ }^{40}$. The novel coronavirus infected mostly the young aged and working people in Bangladesh. As compared to other countries, deaths due to COVID-19 in Bangladesh remain relatively low and the deaths and hospitalized cases are found high among the aged population more specifically among the aged male population. Bangladesh is now taking advantage of the demographic dividend to protect the young working population as well as the whole nation from the devastation of the ongoing COVID-19 pandemic. Therefore, it is essential to study the patterns of infection and death due to COVID-19. The study aimed to reveal the prevalence of COVID-19 and death due to novel coronavirus in Bangladesh. Another objective of this study is to investigate the patterns of infection and death due to novel coronavirus in Bangladesh by demographic and geographical characteristics.

\section{METHODS}

\section{Data Source}

The data for this study have been collected from the daily press releases of the IEDCR and Directorate General of Health Services (DGHS). Data have been taken for 165 days form March, 18 to August 29, 2020 because the first death case had been reported due to COVID-19 on March 18, 2020 in Bangladesh. The collected data were double-checked against IEDCR and DGHS press releases with daily situational reports of the WHO. Bangladesh first confirmed the COVID-19 patients in its territory on March 8, 2020 and still it is continuing. On August 29, 2020, the country had reported 308925 infected cases of COVID-19 disease, 198863 recovered cases and the death total stood at $4206^{38}$. An infected patient of COVID-19 is defined who exposed a positive result in a respiratory specimen of nucleic acid and death incidence is reported who was first infected by SARSCoV-2 before dying. The percentage of daily infected cases to tests has been computed dividing daily infected cases by the number of tests and multiplied by 100 . Daily active cases have been found by subtracting daily cumulative recovered and deaths from daily cumulative infected cases.

\section{Statistical Methods}

The sex ratio is the ratio between males to females in a 
population. It is expressed in percentage and indicates how much higher or lower is the male population than its counter female population. Doubling time is an important concept in epidemiology and refers to a duration by which any quantity becomes double in size. Therefore, the time at which cumulative incidences become double is referred to as the doubling time of the incidences. A correlation coefficient is a statistical tool used to assess the strength and direction of the relationship between two numerical variables. It ranges from -1 to +1 . A high value of the correlation coefficient indicates a strong relationship between two variables, while a low value denotes the weak relationship. The sign of the coefficient indicates the direction of the relationship. A scatter plot is also used to display the relationship between two variables. A line chart is used to investigate the pattern of an incidence according to time. A bar chart is used to display and compare the various categories of attributes. Figures have been created using $\mathrm{R}$ software version
4.0.2 and percent infections, percent active cases, percent deaths, doubling time have been calculated using Microsoft Excel version 13 .

\section{RESULTS}

The infection rate to tests due to novel coronavirus in Bangladesh till August 29, 2020 was 20.25\%. The recovery rate according to reported infections till August 29, 2020 was $64.37 \%$. The sex ratio of male to female in deaths is $364.23 \%$ that is 364 males have died against 100 female deaths due to COVID-19 infections. Table-1 represents the daily percent infections, doubling times of infections and deaths, daily percent active cases and deaths to infections due to novel coronavirus in Bangladesh. The first deaths occurred in Bangladesh on March 18, 2020 and it became double on March 21, 2020.

Table 1. Doubling time of infections, deaths, daily \% infections, active cases, and deaths due to SARS-CoV-2 in Bangladesh as of August 29, 2020.

\begin{tabular}{lrrrrr}
\hline Dates & $\begin{array}{r}\text { Doubling Time of } \\
\text { Infections (Days) }\end{array}$ & $\begin{array}{r}\text { Doubling Time of } \\
\text { Deaths (Days) }\end{array}$ & $\begin{array}{r}\text { \% Daily Infections } \\
\text { (D Active } \\
\text { Cases }\end{array}$ & $\begin{array}{r}\text { \% Deaths to } \\
\text { Infections }\end{array}$ \\
\hline $18-03-2020$ & 3 & 0 & 40 & 71.429 & 7.143 \\
$19-03-2020$ & 3 & 0 & 6.522 & 76.471 & 5.882 \\
$20-03-2020$ & 3 & 0 & 8.333 & 80 & 5 \\
$21-03-2020$ & 4 & 3 & 11.111 & 79.167 & 8.333 \\
$22-03-2020$ & 5 & 4 & 4.615 & 74.074 & 7.407 \\
& 5 & $\vdots$ & $\vdots$ & $\vdots$ & $\vdots$ \\
$25-08-2020$ & 55 & 52 & 17.982 & 36.326 & 1.344 \\
$26-08-2020$ & 55 & 52 & 16.715 & 35.705 & 1.351 \\
$27-08-2020$ & 56 & 53 & 16.107 & 35.129 & 1.355 \\
$28-08-2020$ & 57 & 53 & 16.091 & 34.480 & 1.361 \\
$29-08-2020$ & 57 & 54 & 18.231 & 34.266 & 1.361 \\
\hline
\end{tabular}

Figure-1 reveals the current situation of COVID-19 in Bangladesh. From Figure-1(A), cumulative infections were not highly fluctuated till the middle of April, 2020 but rapidly increased over time from the middle of April, 2020 and reached at 308925 as of August 29, 2020. Cumulative deaths were increased over time and it reached 4206 as of August 29, 2020. From Figure$1(B)$, the percent active cases fluctuated over time and gradually started decreasing from May 03, 2020 and it was continuing till
August 29, 2020. Percent infections to tests highly fluctuated at the beginning and had an increasing trend then showed decreased at the last week of August, 2020. From Figure-1(C), daily deaths due to COVID-19 disease in Bangladesh fluctuated over time and reached its maximum 64 on June 30, 2020. The percent deaths to infections fluctuated at the beginning and then had a decreasing trend till August 29, 2020. 
Figure 1. Current situation of COVID-19 in Bangladesh. A) Daily cumulative infections and deaths in Bangladesh; B) Daily \% Infections with tests and daily \% active cases; C) Number of daily deaths and daily \% deaths to reported infections.

A

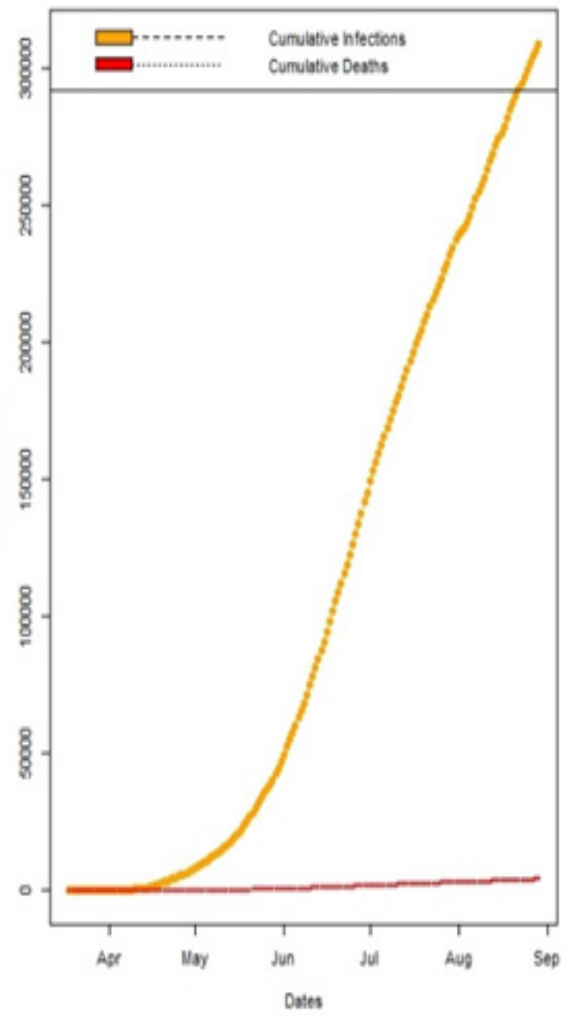

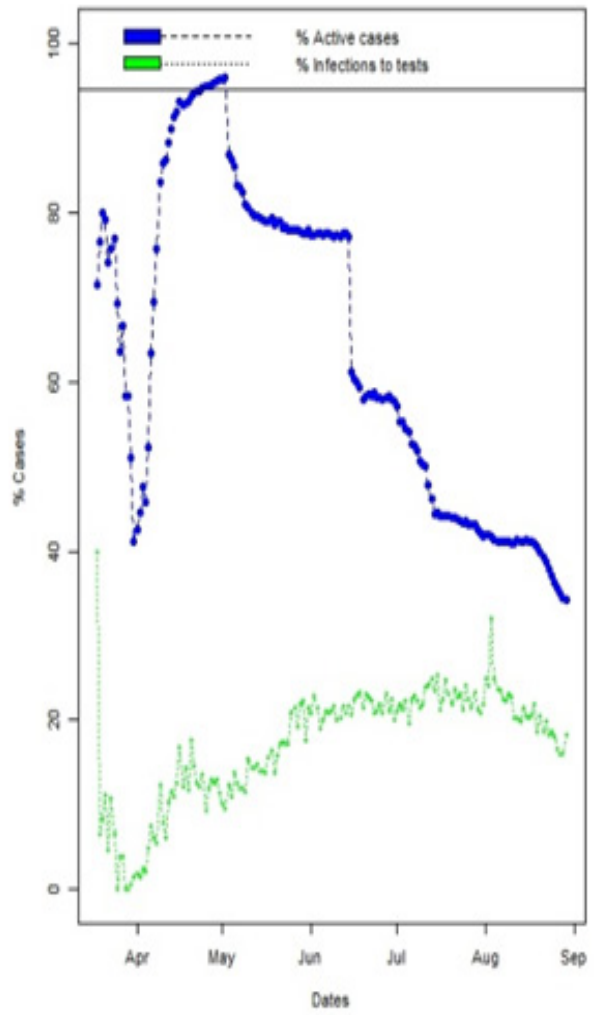

C

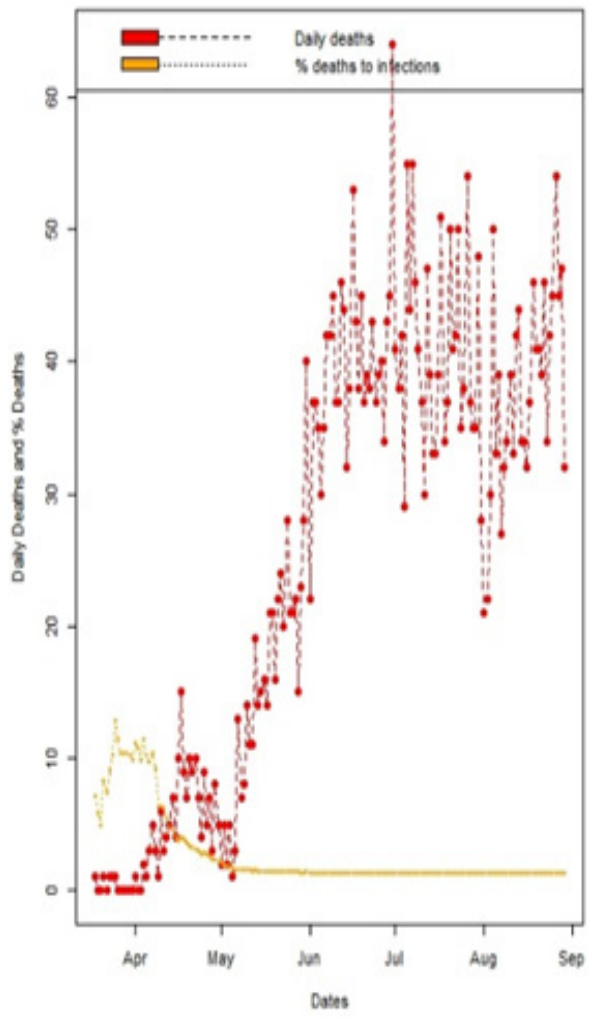

Deaths by demographic and spatial characteristics are presented in Table-2. Aged people are most vulnerable to death. Male are more prevalent in deaths compare to females. The most deaths occurred in the Dhaka division and the least deaths in the Mymensingh division.

Table 2. Deaths by age group, sex and divisions due to SARSCoV-2 in Bangladesh as of August 29, 2020

\begin{tabular}{|c|c|c|c|c|c|}
\hline Age Group & Deaths & Sex & Deaths & Divisions & Deaths \\
\hline $0-10$ & 19 & & & Dhaka & 2030 \\
\hline $11-20$ & 36 & Male & 3300 & Chittagong & 920 \\
\hline $21-30$ & 100 & & & Rajshahi & 279 \\
\hline $31-40$ & 257 & & & Khulna & 348 \\
\hline $41-50$ & 566 & & & Barishal & 165 \\
\hline \multirow[t]{2}{*}{$51-60$} & 1156 & & & Sylhet & 191 \\
\hline & & Female & 906 & Rangpur & 184 \\
\hline $60+$ & 2072 & & & Mymensingh & 89 \\
\hline
\end{tabular}

The correlation coefficient between daily tests conducted in the last 24 hours and daily reported infections in Bangladesh as of August 29, 2020 has found 0.978 with a $95 \%$ confidence interval 0.971 to 0.984 . The $p$-value of the coefficient was $<0.05\left(2.2 \times 16^{-16}\right)$ which indicates the correlation coefficient is significant. There is a strong positive relationship between daily conducted tests and the daily number of infections with the increase of tests in the last 24 hours, the number of reported infections also increased. The scatter plot also suggests that there is a linear increasing relationship between tests in the last 24 hours and the number of infections as shown in Figure-2 (A). The doubling time of the novel coronavirus infections and deaths in Bangladesh increased over time. The range of the estimates of doubling time for COVID-19 infection and deaths in Bangladesh is 2 to 57 days and 3 to 54 days respectively as of August 29, 2020. Figure-2 (B) indicates the doubling time of infections and deaths for COVID-19 in Bangladesh. Doubling time was much smaller at the beginning of the outbreak of novel coronavirus in Bangladesh and increased as days goes for both infections and deaths. The growth of doubling time for deaths increased faster than that of infections until the middle of May, 2020. Both rates have been increasing very sharply from the middle of May, 2020 keeping very low differences between them. Doubling time of deaths was greater than infections till July, 2020 then started decreasing with time.

It has been found that $78.46 \%$ of males have died due to COVID-19 while only $21.54 \%$ of females have died in Bangladesh by SARS-CoV-2 as of August 29, 2020 as shown in Figure-2 (C). The deaths of male groups are much higher than the female group due to COVID-19 in Bangladesh. Percent deaths by age group in Bangladesh reveal that below 10 age group is the least prevalent $(0.45 \%)$ of deaths due to COVID-19 in Bangladesh. 
Usually, children remained at home at the time of pandemic and had not to get in contact with the people who are not their family members. This may be the main cause of the least deaths of this group. With the increase of age among groups, death rates due to novel coronavirus have also increased. This may have happened because aged people had to go outside for their living. Moreover, comorbidities grasp the people with an increase of their age. The age group above 60 is the most prevalent $(49.26 \%)$ to deaths and this may be the reason for multiple comorbidities in Bangladesh due to SARS-CoV-2 (Figure-2(D)).

Figure 2: (A) Scatter plot between daily tests and daily infections; (B) Doubling time of infection and deaths; (C) Bar plot of \% deaths by sex; (D) Bar plot of \% deaths by age due to COVID-19 disease in Bangladesh as of August 29, 2020.
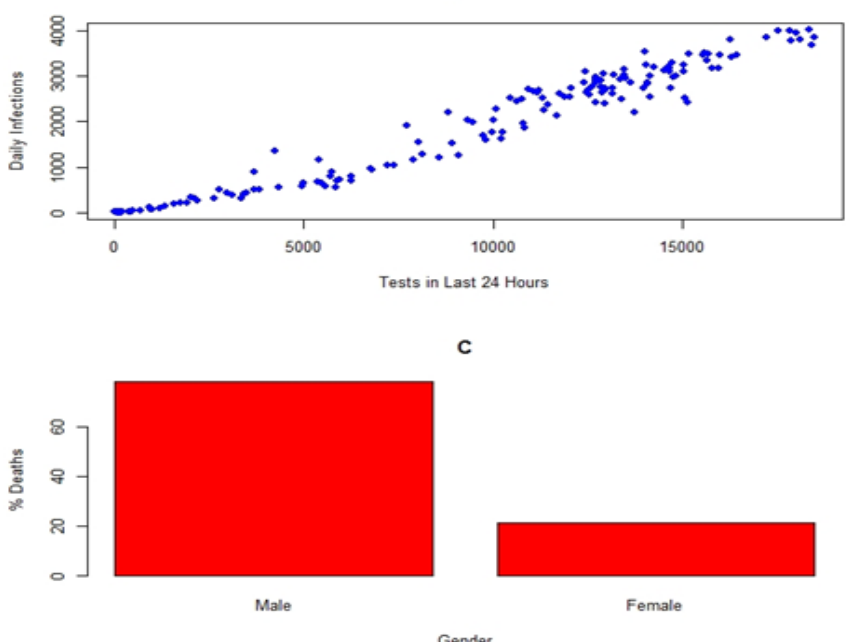

It is found that among 4206 deaths due to SARS-CoV-2 in Bangladesh as of August 29, 2020, almost half of the deaths (48.26\%) occurred in the Dhaka division. Dhaka is the capital of Bangladesh and almost all the administrative and businessoriented works are centered in Dhaka. Also, Dhaka is the most densely populated division in Bangladesh which may be the cause of high death rate due to COVID-19 disease. The second most deaths (21.87\%) division is Chittagong which is geographically largest of all eight divisions in Bangladesh and also known as the commercial capital of Bangladesh. The least
B
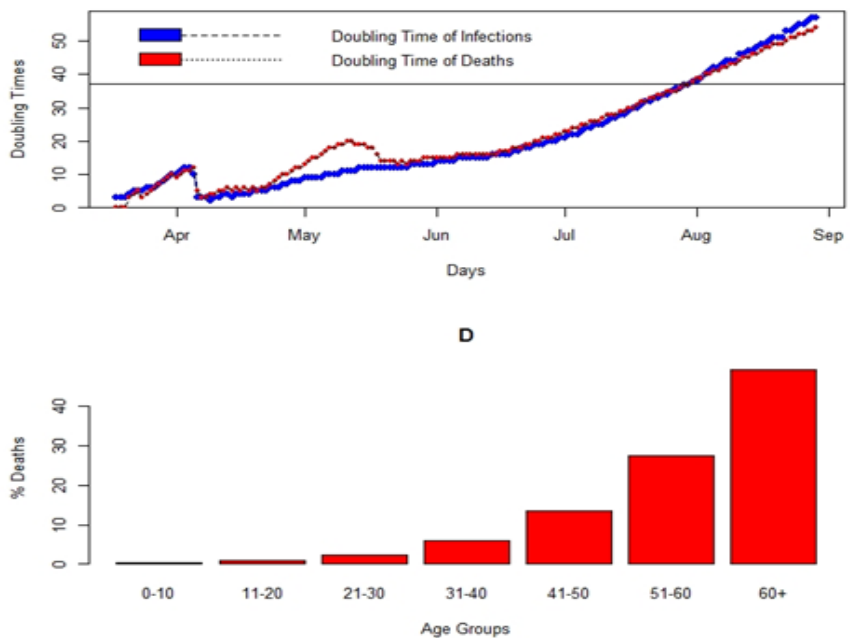

death prevalent $(2.12 \%)$ division is Mymensingh which is the newest and geographically smallest division in Bangladesh (Figure-4 (A)). The patients who had comorbidities other than COVID-19 are highly prone to deaths. Data on the proportion of patient's deaths by comorbidity status are taken from IEDCR website from July 15 to August 29, 2020 (corona.gov.bd). The COVID-19 patients with diabetes are highly prone to deaths $(38 \%)$, patients with hypertension $(28 \%)$ are also highly prone to deaths, and patients with stroke and asthma (3\%) are least prone to deaths (Figure-4 (B)).

Figure 3. Bar chart of (A) \% deaths by division due to COVID-19 disease in Bangladesh as of August 29, 2020; (B) Proportion of deaths by comorbidity status.
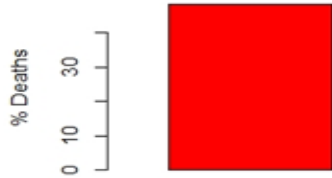

Dhaka

Chittagong
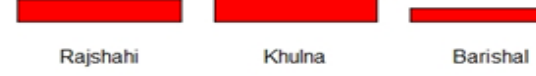

Divisions

B

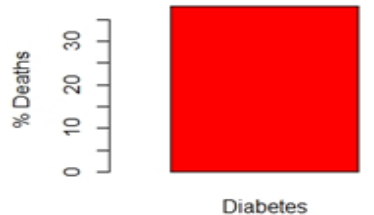

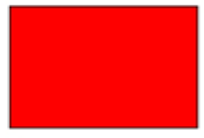

Hypertension

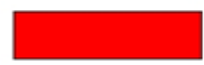

Heart Failure

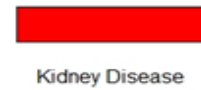

Comorbidities

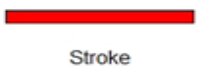

Stroke
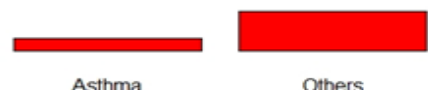

Others 


\section{DISCUSSION}

The main purpose of the study was to reveal the prevalence of COVID-19 and death due to novel coronavirus in Bangladesh. Also objective was to investigate the patterns of infection and death due to novel coronavirus in Bangladesh by demographic and geographical characteristics.

The novel coronavirus (SARS-CoV-2) was first identified in Wuhan, Hubei province, China on December 31, 2019. Then, it outbreaks in 216 countries (WHO) across the world. Three cases were first reported in Bangladesh on March 08, 2020 by IEDCR through Reverse Transcription Polymerase Chain Reaction (RT$P C R)$ testing. The first death case was found in Bangladesh due to a novel coronavirus infection on March 18, 2020. The maximum reported death cases were 64 due to SARS-CoV-2 in Bangladesh that was found on June 30, 2020 and the maximum reported infected cases in a day so far is 4019 which was found on July 02,2020 . The main objective of this study was to reveal the prevalence and patterns of infection and deaths due to SARS-Cov-2 in Bangladesh by demographic and geographical characteristics.

The COVID-19 cases in Bangladesh increased significantly over time. The testing rate rose significantly in Bangladesh from the first detection of COVID-19 patients. The correlation coefficient between daily tests and reported infections indicates a strong positive relationship. The correlation coefficient and scatter plot specify that, with the increase of daily conducted tests, daily reported infections were also increased. The doubling time of the reported infections and deaths was almost similar at the beginning but the doubling time of deaths suddenly started to increase from April 24 and the value was more than infections till May 18, 2020. From May 19, 2020, the doubling time of both cases increased very sharply keeping very small differences. The sex ratio of deaths indicates about 364 male people had died due to SARS-CoV-2 against 100 females. Male people have died almost 3.5 times than females by SARS-CoV-2 in Bangladesh as of August 29, 2020. The deaths due to SARS-CoV-2 were increased with ages. The age group below 10 was the least dominant and the age group above 60 was most vulnerable to deaths due to SARS-CoV-2 in Bangladesh as of August 29, 2020. Dhaka division was the most prevalent to deaths and Mymensingh division was the least prevalent to deaths due to SARS-CoV-2 in Bangladesh as of August 29, 2020.

The tests were increased in Bangladesh for time being and also the number of infections also increased in Bangladesh with time. There had a strong positive relationship between daily tests and infections. The number of days to double infections and deaths increased very sharply with time maintaining a minor difference. Male people are more vulnerable to be infected and to be died than females in Bangladesh by SARS-CoV-2. Deaths are increased with an increase in ages. People who are above 60 years are severely vulnerable to death. About 364 male people had died due to SARS-CoV-2 against 100 females. The maximum deaths occurred in the Dhaka division and the least deaths occurred in the Mymensingh division.

\section{ACKNOWLEDGEMENTS}

We would like to acknowledge the IEDCR and DGHS of Bangladesh for making public the daily data which helps us to conduct this study.

\section{REFERENCES}

1. Walker PG, Whittaker C, Watson OJ, Baguelin M, Winskill P, Hamlet A, et al. The impact of COVID-19 and strategies for mitigation and suppression in lowand middle-income countries. Science. 2020 Jun 12; 370(6502): 413-22. doi: https://doi.org/10.1126/science.abc0035. Pubmed PMID: 32532802.

2. Rana MS, Rony MA, Aktar N, Hossain K, Shuvo TA, Begum S, et al. Effect of COVID-19 in Bangladesh: Challenge and Overcome. J Appl Sci Eng Technol Educ. 2020 Jul 15; 3(1): 53-68. doi: https://doi.org/10.35877/454RI.asci128.

3. Chen H, Guo J, Wang C, Luo F, Yu X, Zhang W, et al. Clinical characteristics and intrauterine vertical transmission potential of COVID-19 infection in nine pregnant women: a retrospective review of medical records. Lancet. 2020 Mar; 395(10226): 809-815. doi: https://doi.org/10.1016/S0140-6736(20)30360-3. Pubmed PMID: 32151335.

4. Rajgor DD, Lee MH, Archuleta S, Bagdasarian N, Quek SC. The many estimates of the COVID-19 case fatality rate. Lancet Infect Dis. 2020 Jul; 20(7): 776-7. doi https://doi.org/ 10.1016/S1473-3099(20)30244-9. Pubmed PMID: 32224313.

5. Nikpouraghdam M, Farahani AJ, Alishiri G, Heydari S, Ebrahimnia M, Samadinia $\mathrm{H}$, et al. Epidemiological characteristics of coronavirus disease 2019 (COVID-19) patients in IRAN: A single center study. J Clin Viro. 2020 Jun; 127: 104378. . doi: https://doi.org/10.1016/j.jcv.2020.104378. Pubmed PMID: 32353762.

6. Zu ZY, Jiang MD, Xu PP, Chen W, Ni QQ, Lu GM, et al. Coronavirus Disease 2019 (COVID-19): A Perspective from China. Radiology. 2020 Feb 21; 296(2): 200490. DOI: https://doi.org/10.1148/radiol.2020200490. Pubmed PMID: 32083985.
7. Yang S, Cao P, Du P, Wu Z, Zhuang Z, Yang L, et al. Early estimation of the case fatality rate of COVID-19 in mainland China: a data-driven analysis. Ann Transl Med. 2020 Feb; 8(4): 128. doi: https://doi.org/10.21037/atm.2020.02.66. Pubmed PMID: 32175421.

8. Bernheim A, Mei X, Huang M, Yang Y, Fayad ZA, Zhang N, et al. Chest CT findings in coronavirus disease-19 (COVID-19): relationship to duration of infection. Radiology. 2020 Feb. 295(3): 200463. doi: https://doi.org/10.1148/ radiol.2020200463. Pubmed PMID:32077789.

9. Kang YJ. Characteristics of the COVID-19 Outbreak in Korea From the Mass Infection Perspective. J Prev Med Public Health. 2020 May; 53(3): 168-170. doi: https://doi.org/10.3961/jpmph.20.072. Pubmed PMID: 32498139.

10. Sun P, Lu X, Xu C, Sun W, Pan B. Understanding of COVID-19 based on current evidence. J Med Virol. 2020 Jun; 92(6): 548-51. doi: https://doi.org/10.1002/ jmv.25722. Pubmed PMID: 32096567.

11. Mannan DK, Mannan KA. Knowledge and perception towards Novel Coronavirus (COVID 19) in Bangladesh. Int Res J Bus Soc Sci. 2020 Apr; 6(2). doi: https://doi.org/10.2139/ssrn.3576523.

12.Sohrabi C, Alsafi Z, O'Neill N, Khan M, Kerwan A, Al-Jabir A, et al. World Health Organization declares global emergency: A review of the 2019 novel coronavirus (COVID-19). Int J Surg. 2020 Feb; 76: 71-76. doi: https://doi. org/10.1016/j.ijsu.2020.02.034. Pubmed PMID: 32112977.

13. Alimohamadi $\mathrm{Y}$, Taghdir $\mathrm{M}$, Sepandi $\mathrm{M}$. The estimate of the basic 
reproduction number for novel coronavirus disease (COVID-19): a systematic review and meta-analysis. J Prev Med Public Health. 2020 May; 53(3): 151-157. doi: https://doi.org/10.3961/jpmph.20.076. Pubmed PMID: 32498136.

14. Valeriani G, Vukovic IS, Mollica R. Unconventional Answers to Unprecedented Challenges: The Swedish Experience During the COVID-19 Outbreak. J Prev Med Public Health. 2020 Jul 22; 53(4): 233-235. doi: https://doi.org/10.3961/ jpmph.20.235. Pubmed PMID: 32752592.

15. Muyeed A, Siddiqi MN. Prevalence and Severity of COVID-19 Disease in Bangladesh: A Trend Analysis. J Health Biol Sci. 2020 Jun 24; 8(1): 1-8. doi: http://dx.doi.org/10.12662/2317-3076jhbs.v8i1.3285.p1-8.2020.

16. Directorate General of Health Services. Press release regarding COVID-19 situation on August 30, 2020 [Internet]. Ministry of Health and Family Welfare, Government of People's Republic of Bangladesh. [Accessed on 30 Aug 2020]. Available from: https://corona.gov.bd/storage/press-releases/August2020/ OyTD5ZtEyAFDnVDd5ve4.pdf.

17. World Health Organization. WHO Coronavirus Disease (COVID-19) Dashboard [Internet]. Geneva: WHO; 2020 [Accessed on 29 Aug 2020]. Available from: https://covid19. who.int/?gclid=Cj0KCQjwv7L6BRDxARIsAGj34pGU89c9W2Mw OoZsWunhpS-7v05rV8mP-7k5sWsX217ZVO8qDjOBW8aAu7jEALw_wcB.

18. Hossain I, Khan MH, Rahman MS, Mullick AR, Aktaruzzaman MM. The epidemiological characteristics of an outbreak of 2019 novel coronavirus diseases (COVID-19) in Bangladesh: A descriptive study. J Med Sci. Clin Res. 2020 Apr; 8(04): 544-551. doi: https://dx.doi.org/10.18535/jmscr/v8i4.94.

19. Velavan TP, Meyer CG. The COVID-19 epidemic. Trop Med Int Health. 2020 Mar; 25(3): 278-280. doi: https://doi.org/ 10.1111/tmi.13383. Pubmed PMID: 32052514

20. Hossain I, Mullick AR, Khan MH, Ahmad SA, Rahman MS, Aktaruzzaman MM. Epidemiology of Coronavirus Disease: Past, Present, Future Prospects and Its Journey Towards Bangladesh. Int Med J [Internet]. 2020 Jun [accessed on 29 Aug 2020]; 25(06): 2517-2529. Available from: https:// www.researchgate.net/profile/Manzurul_Khan/publication/342470329_ Epidemiology_of_Coronavirus_Disease_Past_Present_Future_Prospects_ and_Its_Journey_Towards_Bangladesh/links/5ef6322545851550507319f3/ Epidemiology-of-Coronavirus-Disease-Past-Present-Future-Prospects-and-ItsJourney-Towards-Bangladesh.pdf.

21. Lauer SA, Grantz KH, Bi Q, Jones FK, Zheng Q, Meredith HR, et al. The incubation period of coronavirus disease 2019 (COVID-19) from publicly reported confirmed cases: estimation and application. Ann Intern Med. 2020 May; 172(9): 577-82. doi: https://doi.org/10.7326/M20-0504. Pubmed PMID: 32150748

22. Acter T, Uddin N, Das J, Akhter A, Choudhury TR, Kim S. Evolution of severe acute respiratory syndrome coronavirus 2 (SARS-CoV-2) as coronavirus disease 2019 (COVID-19) pandemic: A global health emergency. Sci Total Environ. 2020 Apr; 730: 138996. doi: https://doi.org/10.1016/j.scitotenv.2020.138996. Pubmed PMID:32371230.

23. Islam SD, Bodrud-Doza M, Khan RM, Haque MA, Mamun MA. Exploring COVID-19 stress and its factors in Bangladesh: A perception-based study. Heliyon. 2020 Jul; 6(7): e04399. doi: https://doi.org/10.1016/j.heliyon.2020. e04399. Pubmed PMID: 32685726.

24. Garg G. COVID-19 Pandemic: The Ayurvedic Perspective. Int J Ayurveda Tradit Med [Internet]. 2020 Jun [accessed on 29 Aug 2020]; 2(2): 1-2. Available from: https://ijatm.org/index.php/ijatm/article/view/40.

25.Hernández-Vásquez A, Azañedo D, Vargas-Fernández R, Bendezu-Quispe G. Association of comorbidities with pneumonia and death among COVID-19 patients in Mexico: A nationwide cross-sectional study. J Prev Med Public Health. 2020 Jul; 53(4): 211-219. doi: https://doi.org/10.3961/jpmph.20.186. Pubmed PMID: 32752589.

26. Alkhouli M, Nanjundappa A, Bates MC, Bhatt DL. Sex Differences in Case Fatality Rate of COVID-19: Insights From a Multinational Registry. Mayo
Clin Proc. 2020 May; 95(8): 1613-1620. doi: https://doi.org/10.1016/j. mayocp.2020.05.014. Pubmed PMID: 32753136.

27. Ahmed O, Faisal RA, Sharker T, Lee SA, Jobe MC. Adaptation of the Bangla version of the COVID-19 Anxiety Scale. Int J Ment Health Addiction. 2020 Jun: 1-12. doi: https://doi.org/10.1007/s11469-020-00357-2. Pubmed PMID: 32837436 .

28. Sharma G, Volgman AS, Michos ED. Sex differences in mortality from COVID-19 pandemic: are men vulnerable and women protected?. JACC: Case Rep. 2020 Jul; 2(9): 1407-1410. doi: https://doi.org/10.1016/j. jaccas.2020.04.027. Pubmed PMID: 32373791.

29. Dowd JB, Andriano L, Brazel DM, Rotondi V, Block P, Ding X, et al. Demographic science aids in understanding the spread and fatality rates of COVID-19. Proc Natl Acad Sci. 2020 May; 117(18): 9696-9698. doi: https://doi. org/10.1073/pnas.2004911117. Pubmed PMID: 32300018.

30. Wang L, He W, Yu X, Hu D, Bao M, Liu H, et al. Coronavirus disease 2019 in elderly patients: Characteristics and prognostic factors based on 4-week follow-up. J Infect. 2020 Jun; 80(6): 639-645. doi: https://doi.org/10.1016/j. jinf.2020.03.019. Pubmed PMID: 32240670.

31. Liu K, Chen Y, Lin R, Han K. Clinical features of COVID-19 in elderly patients: A comparison with young and middle-aged patients. J Infect 2020 Jun; 80(6): e14-e18. doi: https://doi.org/10.1016/j.jinf.2020.03.005. Pubmed PMID: 32171866.

32. Klein SL, Dhakal S, Ursin RL, Deshpande S, Sandberg K, Mauvais-Jarvis F. Biological sex impacts COVID-19 outcomes. PLoS Pathog. 2020 Jun; 16(6): e1008570. doi: https://doi.org/10.1371/journal.ppat.1008570. Pubmed PMID: 32569293.

33. Froldi G, Dorigo P. Endothelial dysfunction in Coronavirus disease 2019 (COVID-19): Gender and age influences. Med Hypotheses. 2020 Jun 20; 144: 110015. doi: https://doi.org/ 10.1016/j.mehy.2020.110015. Pubmed PMID: 32592919.

34. Ansari-Lari M, Saadat M. The morbidity and mortality of COVID-19 are associated with $\mathrm{ABO}$ and Rh blood groups. Eur J Prev Cardiol. 2020 Jul 7:2047487320939216. doi: https:// 10.1177/2047487320939216. Pubmed PMID: 32635755.

35. Mohiuddin AK. COVID-19 and 20 Resolutions for Bangladesh. Eur J Sustai Dev Re. 2020 Jul; 4(4): em0139. doi: https://doi.org/10.29333/ejosdr/8433.

36. Islam MN, Islam AN. A systematic review of the digital interventions for fighting COVID-19: the Bangladesh perspective. IEEE Access. 2020 Jun 15; 8: 114078-114087. doi: https://doi.org/10.1109/ACCESS.2020.3002445.

37. Sakamoto M, Begum S, Ahmed T. Vulnerabilities to COVID-19 in Bangladesh and a Reconsideration of Sustainable Development Goals. Sustainability. 2020 Jun 30; 12(13): 5296. doi: https://doi.org/10.3390/su12135296.

38. Directorate General of Health Services. Press release regarding COVID-19 situation on August 29, 2020 [Interenet]. Ministry of Health and Family Welfare, Government of People's Republic of Bangladesh. [accessed 29 Aug 2020]. Available from: https://corona.gov.bd/storage/press-releases/ August2020/4KWrWKZrPjMTDo8Jh0By.pdf

39. Kabir H, Maple M, Usher K. The impact of COVID-19 on Bangladeshi readymade garment (RMG) workers. J Public Health [Internet]. 2020 Jul 31 [accessed on 29 Aug 2020]: fdaa126. Available from: https://academic.oup. com/jpubhealth/advance-article/doi/10.1093/pubmed/fdaa126/5879065. doi: https://doi.org/10.1093/pubmed/fdaa126. Pubmed PMID: 32734293.

40. Shammi M, Bodrud-Doza M, Islam AR, Rahman MM. Strategic assessment of COVID-19 pandemic in Bangladesh: comparative lockdown scenario analysis, public perception, and management for sustainability. Environ Dev Sustain [Internet]. 2020 Jul [accessed on 29 Aug 2020]:1-44. Available from https://link. springer.com/content/pdf/10.1007/s10668-020-00867-y.pdf. doi: https://doi. org/10.1007/s10668-020-00867-y. Pubmed PMID: 32837281.

\section{How to cite this article/ Como citar este artigo:}

Muyeed A, Siddiqi MNA, Saha TK, Goni MA. Infection and Death Patterns of COVID-19 Disease in Bangladesh. J Health Biol Sci. 2020 J; 8(1):1-7. 